\title{
Nagib, Lúcia: World Cinema and the Ethics of Realism. London: Continuum, 2011.
}

\author{
Júlia Machado de Carvalho ${ }^{1}$
}

Em World Cinema and the Ethics of Realism (2011), Lucia Nabig aborda os modos realistas de produção e endereçamento, típicos das novas ondas cinematográficas, através da análise comparativa de filmes de origens diversas em espaço-tempo (Cinema Novo japonês, Nouvelle Vague francesa, Cinema Novo brasileiro, Novo Cinema alemão, o cinema revolucionário russo-cubano, além dos filmes do autor português autoperformático João César Monteiro e dos dos inuítes Idrissa Ouédraogo e Zacharias Kunuk). A autora rompe com as categorizações de ficção e documentário, cinema de arte e cinema mainstream, cinema europeu e latinoamericano, para repensar alguns conceitos fundamentais nos estudos de cinema, tais como ilusionismo, identificação, aparato, efeito de alienação, apresentação e representação. World Cinema and the Ethics of Realism é, portanto, leitura indispensável para quem está interessado nas questões estéticas que permeiam os ápices de expressão criativa do cinema mundial.

A publicação integra a série Tauris World Cinema (editada pela autora), e é baseada em uma abordagem multicultural e policêntrica dos estudos de cinema, cujo Unthinking Eurocentrism (Ella Shohat e Robert Stam, 1994) é importante marco de referência. Ao romper com a divisão cartesiana de sujeito-objeto, seja em se tratando de corpo e mente, ator e espectador, diretor e personagem, centro e periferia, o método de análise de Nagib permite observar as profundas afinidades estéticas de uma "ética do realismo" que permeia a história do cinema. Segundo a autora, com o advento da tecnologia digital o conceito de mimesis retorna ao centro de discussão dos estudos de

\footnotetext{
${ }^{1}$ Doutoranda em Estética e Comunicação na Universidade de Aarhus, Dinamarca.
}

Brasiliana - Journal for Brazilian Studies. Vol. 1, n.1 (Sept. 2012). ISSN 2245-4373. 
cinema pois que a perda da relação direta entre imagem e referente instaura uma nova problemática na questão da reprodutibilidade. E é através do entendimento do cinema como duo de realismo e simulação, como afirma Siegfried Krakauer, que a autora vai estabelecer seu diálogo com o realismo fenomenológico do pensador e crítico André Bazin - pedra angular do livro.

A preocupação ética com a fidelidade na apresentação do fenômeno pró-fílmico revela-se em alguns aspectos destacados a partir da análise dos filmes: a) a ideia de um realismo físico que se dá no corpo de atores e equipe; b) em lugar da representação, a apresentação da situação necessariamente vivida por aqueles que fazem o filme - atores e equipe; c) o comprometimento físico que a cena implica aos corpos confere verdade à cena; d) e o caráter ético que reside nessa "entrega" imprime, por fim, uma dimensão realista ao filme, independende de sua dimensão ficcional.

No primeiro capítulo do livro, Nagib observa a presença em comum do "personagem que corre a pé" nos filmes O Corredor (Atanarjuat, Zacharias Kunuk 2001), Yaaba (Idrissa Ouédraogo, 1989), Deus e o Diabo na Terra do Sol (Glauber Rocha, 1964) e Os Incompreendidos (Les Quatre Cents Coups, Truffaut, 1959). Esses corredores, enquanto no papel de protragonistas, arrastam a câmera pelo território de suas ações, que não se encaixam como motivo dentro da coerência ficcional e dirigem, desta maneira, a atenção do espectador para a existência física, corporal do ator, ao mesmo tempo que migra lentamente da ficção para o fato. Fisicalidade esta que também marca o cinema de Werner Herzog, que será analisado no capítulo seguinte. A autora observa como o corpo no cinema de Herzog é um índice da influência do Cinema Novo brasileiro em seu estilo cinematográfico, assim como em vários outros filmes do Novo Cinema alemão, do qual este seria o principal exemplo.

$\mathrm{Na}$ segunda parte, a autora vai dissociar realismo conceitual de mimesis narrativa, através da análise dos filmes Terra em Transe (Glauber Rocha, 1967) e Soy 
Cuba (Mikail Kalatozov, 1964). Observa como os filmes encontram na resoluta rejeição da representação mimética - em nome de uma ética do realismo do meio - a forma de preservar seus princípios revolucionários dentro da forma fílmica. Apesar de terem sido filmados em locações, fazendo uso de atores não-profissionais, câmera-na-mão, profundidade de campo e plano-sequência, ambos os filmes tratam da revolução (real ou hipotética) fazendo uso de dispositivos normalmente associados ao anti-realismo, tal como alegoria, linguagem poética, sinédoque e personificação. Salienta que o objetivo, portanto, é menos capturar a realidade tal como ela acontece do que produzir um "real conceitual" no mundo fenomenológico, o que faz esses filmes serem considerados obras-primas cinematográficas.

$\mathrm{Na}$ análise do filme Crime Delicado (Beto Brant, 2005), Nabig observa que, ao filmar o trabalho de arte em processo, Brant vai além do seu valor documental e indexal, para fazer da ficção uma produção de realidade, a partir do engajamento físico dos atriz Lilian Taublib (deficiente física na vida real) e o pintor Felipe Ehrenberg em cenas de nudismo e intimidade sexual. A relação entre erotismo e realismo no cinema segue no capítulo seguinte, inteiramente dedicada ao erotismo no cinema de Nagisa Oshima, especialmente em O Império dos Sentidos (Ai no Koriida, 1976). Nagib revisa alguns conceitos teóricos baseados na oposição entre prazer sexual e intelectual, o que reflete nas questões de gênero, identidade nacional, realismo e espectatorialidade dentro e fora da fábula.

O sexto capítulo é dedicado ao cinema de Kazuo Hara e Sachiko Kobayashi, mais especificamente os fimes Sayonara CP (1972), Gokushiteki erosu: renka 1974 (1974), Yuki yukite shingun (1987) e Zenshin shosetsuka (1994). Nesses filmes, a ideia de um projeto realista baseado na fisicalidade é levado ao extremo, tornando o ato de filmar ao mesmo tempo em produção e reprodução da realidade. A autora observa que raramente o cinema tem sido tão politicamente ativo, ainda que se recuse a enviar mensagens 
políticas diretas. A interferência no campo político da ação é, portanto, delimitada pelos riscos que representa a atores e equipe, e seus filmes, nas palavras da autora, combinam contingência e intenção - combinação que conta para o seu realismo ético. Baseando-se na terminologia de Alain Badiou, Nagib vai denominar de ético o compromisso desse cinema com a verdade do evento imprevisível.

Os filmes autobiográficos do diretor português João César Monteiro são analisados no último capítulo, e resumem, segundo a autora, de maneira exemplar as questões relacionadas à ética e ao realismo em jogo no livro. Nagib observa que Monteiro se preocupa mais com a realidade do desejo do que com o seu gozo, e observa que, ao fazer filmes, Monteiro está também fazendo história, implicando em mudanças na vida real de elenco e equipe, e portanto produzindo uma realidade ética. E cita Lacan, para quem o Real é impossível e é no desejo que se deve botar o acento, pois que visa o impossível, e portanto, o Real.

Pesquisadora brasileira, Lúcia Nagib é responsável por uma considerável produção de pensamento sobre cinema em língua inglesa. Seguindo o conceito de Dudley Andrew em seu Atlas of World Cinema, a autora considera a história do cinema como uma sequência de ondas que permeiam diferentes culturas. Com clareza de escrita e contundência crítica, Nagib realiza em World Cinema and the Ethics of Realism uma importante revisão dos principais pensamentos no campo dos estudos de cinema, passando por Jacques Rancière, Noël Burch, André Bazin, Siegfried Kracauer, Tom Gunning, Noël Carrol, Murray Smith, Vivian Sobchack. Sem deixar de fazer referência a importantes contribuições de pesquisadores como Ismail Xavier, Jean-Claude Bernardet e Ivana Bentes, Lucia Nagib desenha assim um mapa polifônico, onde insere seu pensamento (assim como os estudos de cinema brasileiro) no contexto de discussões do cinema mundial.

Brasiliana - Journal for Brazilian Studies. Vol. 1, n.1 (Sept. 2012). ISSN 2245-4373. 